\title{
Concise Overview on Biomaterial Based Wound Dressing
}

\author{
Zahra Shahravi, Mahsa Mollapour Sisakht*, Shiva Bahrami and Mohammad Amir Amirkhani* \\ Stem Cell and Regenerative Medicine Center of Excellence, Tehran University of Medical Sciences, Iran
}

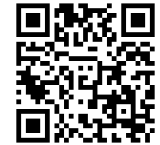

*Corresponding author: Mahsa Mollapour Sisakht and Mohammad Amir Amirkhani, Stem Cell and Regenerative Medicine Center

of Excellence, Tehran University of Medical Sciences, Iran

\begin{abstract}
ARTICLE INFO
Received: 幽 December 16, 2019

Published: January 06, 2020

Citation: Zahra Shahravi, Mahsa Mollapour Sisakht, Shiva Bahrami, Mohammad Amir Amirkhani. Concise Overview on Biomaterial Based Wound Dressing. Biomed J Sci \& Tech Res 24(1)-2020. BJSTR. MS.ID.003997.
\end{abstract}

Keywords: Biomaterial; Wound Dressing; Regenerative Medicine; Skin

\begin{abstract}
In recent years, patients with wounds and ulcers, especially non-healing wounds suffer from medical staff that they can't be more effective as a complete cure. Besides that, in most healthcare settings, these patients have to spend considerable amount of time to get treat at hospitals. Based on the different market studies wound care cause of waste huge amount of money regard to hospitality and human resources. Regenerative medicine as a new therapeutic option, try to combine different methods such as gene therapy, cell therapy, tissue engineering and using small molecules to cure different disease. Using various types of natural and synthetic polymers as a part of tissue engineering with/or without active ingredients introduced from 1980. Due to importance of using material in preparing scaffold, FDA give a definition of tissue engineering as a functional arm of regenerative medicine. The present review traces a brief list of most popular natural and synthetic polymers with introduce interesting commercial products made from each of those polymers.
\end{abstract}

Abbreviations: HA: Hyaluronic Acid; CMC: Carboxymethyl Cellulose; PCL: Poly Caprolactone; PVA: Polyvinyl Alcohol

\section{Introduction}

The skin is the largest and most external organ that covers the whole body [1]. The primary function of the skin is preserved the primary layers of chemical, mechanical and physical factors [2]. The skin also has functions such as temperature regulation, immune barrier to prevent dehydration and production of vitamin D [3]. The skin consists of three layers of epidermis, dermis and hypodermis [4]. The epidermis is thick enough to continue the function as a critical barrier against pathogenic factors [5] and also has a high permeability that prevents bleeding and dehydration [6]. Keratinocyte is the most frequent cell in epidermis [7]. The dermis, located directly below the epidermis layer, forms the bulk of the skin [8]. The dermis is composed of extracellular matrix including collagen, elastin, and glycosaminoglycan, fibroblast and myofibroblast are the most cells in this layer with the role in wound healing [9]. Dermis play main role in flexibility and provides space for vessels, support angiogenesis, the lymphatic system and the nerves. The hypodermis is a layer underneath of the dermis and contains huge amounts of adipose cells that contribute to the mechanical and thermal properties of the skin.

During past decade, different studies in the field of regenerative medicine trigger wound, especially non-healing wound as one of the major problems that can effect on quality of life [10]. Smart wound dressings should design based on the different condition and stage of wound and provide essential growth factor to push wound bed to complete cure like silver-containing products [11]. They have been used for many years as an antimicrobial agent [12] on burn wounds and unlike antibiotics, silver [13] disrupts bacterial cell wall, metabolism and damages intracellular activity [14]. According to different studies in this area, ideal wound dressing should be cost-effective, ease of use, convenient, accessible, consist of pain relief, wound protection against infection, accelerating healing, preventing body fluids lose, flexible, non-allergenic, optimal adhesion to the wound based on wound stage and finally proper mechanical properties [15]. Tissue engineering, cellular therapy 
and gene therapy or in overall, regenerative medicine propose different method that accelerate time of healing significantly.

In compare with standard care (skin graft) for wound healing that have lots of limitation such as the complications of surgery and the lack of skin resources of the patient [3,15], genetic engineering used to manipulate keratinocyte and fibroblast cells to prepare modified skin substitute and prevent graft rejection in Epidermolysis bullosa Besides, tissue engineering using variety of natural and synthetic materials to produce suitable scaffold $[16,17]$ and in combine with cells and/or without cells such as Biobrane $^{\circledR}[18]$, Dermagraft ${ }^{\circledR}$ [19], Integra ${ }^{\circledR}$ [20], Apligraf ${ }^{\circledR}$ [21], Matriderm $^{\circledR}$ [22], Orcel ${ }^{\circledR}$ [23], Hyalomatrix ${ }^{\circledR}$ [24] and Renoskin ${ }^{\circledR}$ [25]. In this study recent list of this kinds of products. But still there are challenges in the using tissue engineering for the treatment of injured organs, different research tried to design scaffolds in membranes or films physical shapes that can mimic the biological structure and function of an extracellular matrixes [26]. Nanofibers as a good option can provide a suitable scaffold for cell attachment, proliferation, migration, and cell growth [27]. In this review, we try to describe natural and synthetic materials that used recently for new generation of wound dressing. Besides that, this review provides data of different commercial products in the field of regenerative medicine.

\section{Natural Biomaterials}

Natural substances are compatible to human skin tissues in their properties. Also, surface modifications can be done to improve cellular interactions based on chemical structure, the natural polymers can be classified into three major classes:

(1) Polysaccharides,

(2) Proteins, and

(3) Lipids [28].

It should be noted, natural polymers have better biological performance than synthetic polymers. Disadvantages of using natural-bio polymer are weak and uncontrollable mechanical properties [29].

\section{Collagen}

Collagen is the most common protein in the extracellular context of skin tissue [30]. It is one of the important regulating factors for the physical and biological properties of the scaffolds [31] and is also an effective factor in cell adhesion. Collagen scaffolds were former kind of scaffold that used in wound dressing [32]. There are different types of commercial products that contain collagen as main component of scaffold like, Integra ${ }^{\circledR}[20]$ made from bovine tendon collagen and shark Glycosaminoglycans (GAGs). Fibracol ${ }^{\circledR}$ from Systagenix that composed of $90 \%$ collagen \& 10\% Calcium Alginate [33]. Helitene ${ }^{\circledR}$ from Integra life science is microfibllilar collagen absorbable hemostatic sponge [34], also Biobrane ${ }^{\circledR}$ from
Smith \& Nephew is artificial skin substitute [18]. BIOstep ${ }^{\circledR}$ is collagen matrix from Smith \& Nephew [35].

\section{Alginate}

Alginates are composed of a numbers of polysaccharide chains containing guluronic acid and Mannuronic acid [28]. Alginate in compare with other biomaterials used more as wound dressing with drug release due to its homeostasis properties. Alginate is an anionic polysaccharide which is used for the preparation of hydrogels at room temperature under normal conditions. This natural polymer is biocompatible, biodegradable, sensible price and easy gelation process [36]. Different shape of Alginate is also used as biomaterial such as gelly like structure that produced by calcium ions as a binding agent. Elasticity properties, absorption of secretions, permeability and ability to create a humid environment in some cases of wound made alginate interesting option as scaffold for tissue engineering [28]. There are different types of commercial products that contain different combination of alginate such as Algivon ${ }^{\circledR}$ from Advancis [37] and Medihoney ${ }^{\circledR}$ [38] from Dermasciences that made from alginate fiber dressing pad impregnated with manuka honey [39]. Kaltostat ${ }^{\circledR}$ from ConvaTec as sodium alginate composite dressing have nonwoven calcium [40]. Carboflex ${ }^{\circledR}$ multi-component dressing consists of alginate and carboxymethylcellulose fibres, bonded to a plastic From ConvaTec [41], Another product is NobAlgin ${ }^{\circledR}$ (Calcium-Alginate-Dressing (contain soft calcium alginate fibers with very high absorption potential [42]. Comfeel ${ }^{\circledR}$ Plus transparent wound dressing contains alginate and hydrocolloid which forms a gel layer upon release of ions from alginate fibers [43].

\section{Honey}

Honey can improve healing process through its antioxidant, antiinflammatory properties. These effects are due to the antimicrobial and osmotic feature of honey. Wound dressing market also consist of variety of products with honey such as MANUKAtex ${ }^{\circledR}$ from ManukaMed as non-adherent gauze dressing impregnated with manuka honey, coated with a dry-touch absorbent hydrocolloid [44]. Medihoney ${ }^{\circledR}$ is Honeycolloid Sheet of gelled manuka honey [45]. MelMax ${ }^{\circledR}$ from Dermagenics as Non-adherent wound dressing impregnated with a mixture of polyhydrated ionogens ointment and buckwheat honey [46]. MelDra ${ }^{\circledR}$ from Dermagenics is Open-weave acetate fabric impregnated with buckwheat honey. HoneySoft ${ }^{\circledR}$ from Taureon is Polyvinylacetate dressing soak with Chilean multifloral honey. Ointment, gel, honey with alginate and Sterile gas entrapped in honey from Dermascience Company [38].

\section{Hyaluronic Acid}

Hyaluronic acid (HA) as one of the main components of the extracellular matrix is a type of glucose aminoglycan found in tissues and in combination with glucuronic acid and $\mathrm{N}$-acetyl glucosamine. HA rapidly degraded in the human body. Hyaluronic acid is a 
natural polysaccharide with appropriate physical and chemical properties to the skin texture that can be effective as a viscoelastic tool. Hyaluronic acid present in various weight and molecular formulation [47]. F Anica hyaluronic acid dressing Hyalofill ${ }^{\circledR}$ [48] $\mathrm{F}$ brand is an absorbent, critical wound coating, contains HYAFF (a component of hyaluronan). Release of hyaluronic acid into the environment is intended to cure and improve the healing process of wet and acute wounds [49]. After rubbing Hyalofill ${ }^{\circledR}$ on the wound, the product not only absorbs the wound secretions, it forms a gel layer due to release of hyaluronic acid on the wound bed. Besides, this company have combination of alginate powder with hyaluronic acid and transparent hyaluronic acid dressing [50].

\section{Aloe Vera}

Aloe Vera contains vitamins, amino acids, minerals, enzymes and glycoproteins. It has been traditionally used for various type of treatment for skin damage such as sun burn and dermatitis [51]. Aloe Vera has anti-inflammatory and antibacterial properties and reduce the inflammation [52], irritation, itching and ulceration associated with radiation-induced dermatitis [53]. It also accelerates the healing of chronic leg ulcers by decreases the blood glucose, surgical wounds and frostbite $[54,55]$.

\section{Chitosan}

Chitin is one of the most widely approachable/accessible polymers due to having multiple functional groups and active structure [56] Although it is biocompatible, biodegradable polysaccharide, well coating for burn wounds and accelerates the healing process. Disadvantage of using chitosan are poor mechanical properties and low electrostatic potential either which is improved in combination with other materials to enhance it. Axiostat ${ }^{\circledR}$ is chitosan hemostatic dressing with US FDA Approval that applies to inhibit moderate to deep bleeding within minutes. This product has anti-inflammatory, pain management, Anti-microbial and hemostatic properties that proper for oral maxillofacial surgeries, dental surgeries and tooth extraction [57]. HemCon ${ }^{\circledR}$ and chitoflex ${ }^{\circledR}$ (HemCon Medical Technologies, Inc., Portland, OR) wound dressings contain chitosan with a special use in homeostasis [58].

\section{Sodium Carboxy Methyl Cellulose (CMC)}

Carboxymethyl cellulose (CMC) or cellulose gum is a cellulose derivative with carboxymethyl groups bound to some of the hydroxyl groups. CMC as a natural polymer is an interesting choice for different companies, commercial products such as Hydroactive Hydrotul ${ }^{\circledR}$ from Hartman which is non-obstructive primary dressing impregnated with non-drug triglyceride ointment [59]. Purilon ${ }^{\circledR}$ gel [60] from Coloplast and Regranex ${ }^{\circledR}$ [61] gel from Smith and Nephew are the most famous example of available products in wound dressing market. AQUACEL ${ }^{\circledR}$ Ag plus, made of fiber and $100 \%$ pure carboxymethyl cellulose. This product produce by Convatec inc. has unique anti-microbial advantages for wounds that are infected or at risk of infection along with ionic silver. This dry dressing is soft, non-woven, adaptable and highly absorbent. ease to use and does not cause scarring or sickness [62]. Another product in this field is ColActive ${ }^{\circledR}$ PLUS Collagen Matrix Dressing is an advanced dressing, after covering wound with this dressing, it make a soft gelatinous layer with optimal moisture content that accelerate granulation and promotes epithelialization, lead to complete wound healing. It consists of sodium alginate, EDTA and CMC [63]. Biatin ${ }^{\circledR}$ alginate from Coloplast contains 85\% calcium alginate and 15\% CMC [64]. Calcium alginate \& CMC can absorb wound exudate, in addition, a gelly structure of these material can fill the cavity of deep wound as well. This gel provide moisture to accelerate wound healing time and pain relief result as a consequence of protection free nerve ending at wound site by this gel [65].

\section{Gelatin}

Gelatin found in ligaments, tendons, and tissues. It can be used as an alternative to collagen due to its properties such as biodegradable and biocompatibility. The pros and cons of using gelatin contain low cost, anti-thrombogenic and anti-inflammatory but it needs chemical bonding and demonstrate less stability $[66,67]$. DouDerm ${ }^{\circledR}$ dressings is composed of a three-dimensional network comprising sodium carboxymethyl cellulose (CMC), pectin, and gelatin that have special arrangement of this triple grid with unique formulation of Convatec America company [68].

\section{Synthetic Polymers}

\section{Poly Caprolactone}

Poly Caprolactone (PCL) is an aliphatic polyester that has been extensively has been studied. This semi-crystalline polyester has high processability and is soluble in a wide range of organic solvents [69]. The limitation of PCL based scaffolds has a hydrophobic property that may affect cell adhesion and degradation rate. Improvement of hydrophilic properties for this polymer is to combine it with hydrophilic polymers [70]. PCL shows biodegradable properties for a long time [71].

\section{Polyvinyl Alcohol}

Polyvinyl alcohol (PVA) is a semi-crystalline hydrophilic polymer; and this polymer consist of a large number of medical products including contact lenses, ophthalmic materials, tendon repair and wound dressing with drug release [72,73] around the world. Proper chemical resistance, biocompatibility, physical properties, high degree of degradation in water or carbon oxide and biodegradability of PVA led to the develop numerous commercial products based on this polymer. PVA has neutral physiology, safe and easy to process, it can crosslink with various agents [10]. Different studies showed that concentration of PVA related to the diameter of the fibers after polymerization.

\section{Poly Lactic Acid/Lactic-Co-Glycolide}

Dextrose from corn or sugar beet is used as the raw material used for to produce poly-lactic acid (PLGA). PLGA belongs to the 
family of aliphatic polyesters, which are usually made of hydroxide acids and this is consider as degradable and combinable materials. PLA is degraded by ester bond through simple hydrolysis and the presence of enzymes is required for the catalytic formation of this hydrolysis [74]. L-Mesitran ${ }^{\circledR}$ from Triticum is soft mixture of honey (not manuka) with lanolin, polyethylene glycol, vitamins C and E [75].

\section{Polyurethane}

Polyurethane has a unique property, has been of interest in wound healing fields. Biatain from coloplast company with PU foam / PU film [65] and ALLEVYN ${ }^{\circledR}$ Ag non-Adhesive from smith and nephew consists of polyurethane and silver [76] are famous products in this filed. FarmActive ${ }^{\circledR}$ foam dressing (polyurethane) as a sterile dressing with three different layers; the upper layer (breathable semi-permeable polyurethane), the middle layer (polyurethane absorbent foam) and the inner layer that can be on the wound bed [77]. Hydrosorb ${ }^{\circledR}$ is a transparent hydrogel dressing from Hartman Company contain hybrid polymers, adsorbent polyurethane and propylene glycol. The back of this dressing is made of polyurethane tape. These types of dressing are not stick to the scar. Transparent wound cover cause to examine the wound even without removing the dressing. The Hydrosorb ${ }^{\circledR}$ coating has a hypoallergenic strip (suitable for people with allergies and allergies) and does not need to use other materials for greater safety [78].

\section{Silicone}

Wound dressing contain silicone provide gentle adhesion, minimizes size of wound and surrounding skin trauma [79]. There is variety of products in world market that contain silicon such as MediClear ${ }^{\circledR}$ Scar from Covalon Company. This dressing is a thin, transparent and self-adhesive silicone consist of a polyurethane film coated with a soft silicone adhesive gel. It can adherent to the areas around the scar and accelerate time of healing or prevent colloidal and hypertrophic scars [80]. Renosigel ${ }^{\circledR}$ from T \& L Company is also another silicone scar removal dressing. Renosigel is a soft, flexible, self-adhesive sheet to improve red and dark scars [81]. Optifoam ${ }^{\circledR}$ as an antibacterial silicone silver foam dressing provides mild adhesion and use after optical surgery, this dressing can be removed from the wound and return to the wound again. The moisture evaporation rate (MVTR) is adjusted according to the amount of discharge [50].

\section{Conclusion}

More than thousand types of dressings are available in the worldwide market that categorized based on the different feature of wounds. Totally, Ideal wound dressing should capable to maintain humidity at the wound bed while removing exudate, free of toxic particle, non-allergic, easy remove from wound, transparent to see process of healing and check time of changing and cost effective. The new generation of wound dressing in the field of regenerative medicine contain live cells that capable complete healing in short time. Actually, nowadays there is variety of products with live cells but still needs more studies to generate different kind of dressing with internal vessels network. This network helps cells to be alive for long time and settle in wound bed till complete healing. Biomaterial that we reviewed in this article after years and years of application still interesting option for physician due to cost effective and ease of use, so, we think more different studies, especially, systematics review needs to show efficacy of using biomaterial in wound healing process.

\section{References}

1. Chua AW, Khoo YC, Tan BK, Tan KC, Foo CL, et al. (2016) Skin tissue engineering advances in severe burns: review and therapeutic applications. Burns \& trauma 4: 3.

2. PB Milan, S Kargozar, MT Joghataie, A Samadikuchaksaraei (2018) Nanoengineered biomaterials for skin regeneration. Nanoengineered Biomaterials for Regenerative Medicine pp. 265-283.

3. MD Leonida, I Kumar (2016) Bionanomaterials for skin regeneration: Springer.

4. A Gangawane, B Bhatt, M Sunmeet (2016) Skin Infections in Diabetes: A Review. J Diabetes Metab 7: 2.

5. L Alonso, E Fuchs (2003) Stem cells in the skin: waste not, Wnt not. Genes \& development 17: 1189-1200.

6. DM Supp, ST Boyce (2005) Engineered skin substitutes: practices and potentials. Clinics in dermatology 23: 403-412.

7. Dai NT, Williamson MR, Khammo N, Adams EF, Coombes AG (2004) Composite cell support membranes based on collagen and polycaprolactone for tissue engineering of skin. Biomaterials 25(18): 4263-4271.

8. Venugopal JR, Zhang Y, Ramakrishna S (2006) In vitro culture of human dermal fibroblasts on electrospun polycaprolactone collagen nanofibrous membrane. Artificial organs 30(6): 440-446.

9. Simões D, Miguel SP, Ribeiro MP, Coutinho P, Mendonça AG (2018) Recent advances on antimicrobial wound dressing: A review. European Journal of Pharmaceutics and Biopharmaceutics 127: 130-141.

10. Saeed SM, Mirzadeh H, Zandi M, Barzin J (2017) Designing and fabrication of curcumin loaded PCL/PVA multi-layer nanofibrous electrospun structures as active wound dressing. Progress in biomaterials 6(1-2): $39-48$.

11. T Maneerung, S Tokura, R Rujiravanit (2008) Impregnation of silver nanoparticles into bacterial cellulose for antimicrobial wound dressing. Carbohydrate polymers 72(1): 43-51.

12. Cencetti C, Bellini D, Pavesio A, Senigaglia D, Passariello C, et al. (2012) Preparation and characterization of antimicrobial wound dressings based on silver, gellan, PVA and borax. Carbohydrate polymers 90(3): 1362-1370.

13. QH Tran, VQ Nguyen, AT Le (2013) Silver nanoparticles: synthesis, properties, toxicology, application and perspectives $4(3)$.

14. Atiyeh BS, Hayek SN, Gunn SW (2005) New technologies for burn wound closure and healing-review of the literature. Burns 31(8): 944-956.

15. Vig K, Chaudhari A, Tripathi S, Dixit S, Sahu R (2017) Advances in skin regeneration using tissue engineering. International journal of molecular sciences 18(4). pii: 789.

16. B Pomahač, T Svensjö, F Yao, H Brown, E Eriksson (1998) Tissue engineering of skin. Critical Reviews in Oral Biology \& Medicine 9(3): 333-344.

17.D Sundaramurthi, UM Krishnan, S Sethuraman (2014) Electrospun nanofibers as scaffolds for skin tissue engineering. Polymer Reviews 54(2): 348-376. 
18. DJ Smith (1995) Use of Biobrane in wound management. The Journal of burn care \& rehabilitation 16(3 Pt 1): 317-320.

19. Gentzkow GD, Iwasaki SD, Hershon KS, Mengel M, Prendergast JJ, et al. (1996) Use of dermagraft, a cultured human dermis, to treat diabetic foot ulcers. Diabetes care 19(4): 350-354.

20. S Mota (2006) Merck v. Integra Lifesciences: The Supreme Court Protects the Use of Patented Compounds in Preclinical Studies. Hamline L Rev 29: 53.

21. Sibbald RG, Torrance GW, Walker V, Attard C, MacNeil P (2001) Costeffectiveness of Apligraf in the treatment of venous leg ulcers. Ostomy/ wound management 47(8): 36-46.

22. Koch L, Deiwick A, Schlie S, Michael S, Gruene M, et al. (2012) Skin tissue generation by laser cell printing. Biotechnology and bioengineering 109(7): 1855-1863.

23. Still J, Glat P, Silverstein P, Griswold J, Mozingo D (2003) The use of a collagen sponge/living cell composite material to treat donor sites in burn patients. Burns 29(8): 837-841.

24. Nicoli F, Balzani A, Lazzeri D, Gentile P, Chilgar RM, et al. (2015) Severe hidradenitis suppurativa treatment using platelet-rich plasma gel and Hyalomatrix. International wound journal 12(3): 338-343.

25. AS Halim, TL Khoo, SJM Yussof (2010) Biologic and synthetic skin substitutes: An overview. Indian journal of plastic surgery: official publication of the Association of Plastic Surgeons of India 43(Suppl): S23-28.

26. CT Laurencin, AMA Ambrosio, M Borden, J Cooper (1999) Tissue engineering: orthopedic applications. Annual review of biomedical engineering 1: 19-46.

27. ZM Huang, YZ Zhang, M Kotaki, S Ramakrishna (2003) A review on polymer nanofibers by electrospinning and their applications in nanocomposites. Composites science and technology 63: 2223-2253.

28. R Pereira, A Carvalho, DC Vaz, M Gil, A Mendes, et al. (2013) Development of novel alginate-based hydrogel films for wound healing applications. International journal of biological macromolecules 52: 221-230.

29. Mogoșanu GD, Grumezescu AM (2014) Natural and synthetic polymers for wounds and burns dressing. International journal of pharmaceutics 463(2): $127-136$

30. G Păunica Panea, A Ficai, MM Marin, Ş Marin, MG Albu, et al. (2016) New collagen-dextran-zinc oxide composites for wound dressing. Journal of Nanomaterials 2016: 5805034

31. Powell HM, Supp DM, Boyce ST (2008) Influence of electrospun collagen on wound contraction of engineered skin substitutes. Biomaterials 29 : 834-843.

32. Li M, Mondrinos MJ, Gandhi MR, Ko FK, Weiss AS, et al. (2005) Electrospun protein fibers as matrices for tissue engineering. Biomaterials 26(30): 5999-6008.

\section{FIBRACOL ${ }^{\mathrm{TM}}$ Plus Collagen Wound Dressing with Alginate.}

34. Oz MC, Rondinone JF, Shargill NS 2003) FloSeal Matrix: new generation topical hemostatic sealant. Journal of cardiac surgery 18(6): 486-493.

35. RH Fitzgerald, JS Steinberg (2009) Collagen in wound healing: are we onto something new or just repeating the past? Foot Ankle Online J 2(9):

36. Zhan X, Hu G, Wagberg T, Zhan S, Xu H, et al. (2016) Electrochemical aptasensor for tetracycline using a screen-printed carbon electrode modified with an alginate film containing reduced graphene oxide and magnetite $\left(\mathrm{Fe}_{3} \mathrm{O}_{4}\right)$ nanoparticles. Microchimica Acta 183(2): 723-729.

37. Thomas A, Harding KG, Moore K (2000) Alginates from wound dressings activate human macrophages to secrete tumour necrosis factor alpha. Biomaterials 21: 1797-1802.

38. P Molan, J Betts (2004) Clinical usage of honey as a wound dressing: an update. Journal of wound care 13(9): 353-356.
39. Mark Collier, Linda Rafter, Mark Rafter, Tim Reynolds, Malcolm West (2017) A clinical evaluation of Algivon ${ }^{\circledR}$ Plus manuka honey dressings for chronic wounds. Wounds UK pp. 132-145.

40. Iliescu Nelea M, Paek L, Dao L, Rouchet N, Efanov JI, et al. (2019) In-situ characterization of the bacterial biofilm associated with Xeroform ${ }^{\mathrm{TM}}$ and Kaltostat $^{\mathrm{TM}}$ dressings and evaluation of their effectiveness on thin skin engraftment donor sites in burn patients. Burns 45: 1122-1130.

41. Thomas S, Fisher B, Fram PJ, Waring MJ (1998) Odour-absorbing dressings. Journal of Wound Care 7(5): 246-250.

42. Wiegand C, Tittelbach J, Hipler U, Elsner P (2015) Clinical efficacy of dressings for treatment of heavily exuding chronic wounds. Chronic Wound Care Manage Res pp. 101-111.

43. Ning Ning, Yang Xiaochun, Chen Haixia (2007) An experimental study on mechanism of Comfeel plus transparent dressing to prevent and treat phlebitis of rabbits. Chinese Nursing Research 7

44. Stewart JA, McGrane OL, Wedmore IS (2014) Wound care in the wilderness: is there evidence for honey? Wilderness \& environmental medicine 25(1): 103-110.

45. PC Molan (2011) The evidence and the rationale for the use of honey as wound dressing. Wound Practice and Research 19(4).

46. AJJ Van Den Berg, MJ Hoekstra (2009) Wound dressings incorporating honey. Google Patents.

47. Goa KL, Benfield P (1994) Hyaluronic acid. Drugs 47: 536-566.

48. M Edmonds, A Foster (2000) Hyalofill: a new product for chronic wound management. Diabetic Foot 3(1): 29-30.

49. Vazquez JR, Short B, Findlow AH, Nixon BP, Boulton AJ, et al. (2003) Outcomes of hyaluronan therapy in diabetic foot wounds. Diabetes research and clinical practice 59(2): 123-127.

50. Ovington LG (2007) Advances in wound dressings. Clinics in dermatology 25: 33-38.

51. MN Shahzad, N Ahmed (2013) Effectiveness of Aloe vera gel compared with $1 \%$ silver sulphadiazine cream as burn wound dressing in second degree burns. J Pak Med Assoc 63(2): 225-230.

52.SP Miguel, MP Ribeiro, P Coutinho, IJ Correia (2017) Electrospun Polycaprolactone/aloe Vera_Chitosan Nanofibrous asymmetric membranes aimed for wound healing applications. Polymers 9(5): 183.

53. MR Farahpour (2019) Medicinal Plants in Wound Healing. Wound Healing-Current Perspectives, (Edi.): IntechOpen.

54. Dat AD, Poon F, Pham KB, Doust I (2012) Aloe vera for treating acute and chronic wounds. Cochrane database of systematic reviews.

55. A Vera (1989) Wound healing, oral \& topical activity of Aloe vera. Journal of the American Podiatric Medical Association 79(11): 559-562.

56.S Song, Y Zhao, X Yuan, J Zhang (2019) $\beta$-Chitin nanofiber hydrogel as a scaffold to in situ fabricate monodispersed ultra-small silver nanoparticles. Colloids and Surfaces A: Physicochemical and Engineering Aspects 574: 36-43.

57. P Ketan, P Anjali, P Rignesh, P Bhavika, P Priyank, et al. (2016) Assessing the Efficacy of Haemostatic Dressing Axiostat ${ }^{\circledR}$ In Trauma Care at a Tertiary Care Hospital in India: A Comparison with Conventional Cotton Gauze. Indian Journal of Emergency Medicine 2(2): 94-99.

58. Lawton G, Granville Chapman J, Parker PJ (2009) Novel haemostatic dressings. Journal of the Royal Army Medical Corps 155(4): 309-314.

59. Meuleneire F, Zoellner P, Swerev M, Holfeld O, Effing J, et al. (2007) A prospective observational study of the efficacy of a novel hydroactive impregnated dressing. Journal of wound care 16(4): 177-182.

60. MG Rippon, J Meadows (2006) Wound gels. (Edn.), Google Patents.

61. Howard JD, Sarojini H, Wan R, Chien S (2014) Rapid granulation tissue regeneration by intracellular ATP delivery-a comparison with regranex. PloS one 9(3): e91787. 
62. Caruso DM, Foster KN, Hermans MH, Rick C (2004) Aquacel Ag in the management of partial-thickness burns: Results of a clinical trial. The Journal of burn care \& rehabilitation 25(1): 89-97.

63. D Brett (2008) A review of collagen and collagen-based wound dressings. Wounds 20(12): 347-356.

64. Ausili E, Paolucci V, Triarico S, Maestrini C, Murolo D, et al. (2013) Treatment of pressure sores in spina bifida patients with calcium alginate and foam dressings. Eur Rev Med Pharmacol Sci 17(12): 16421647

65. P Humbert, F Zuccarelli, C Debure, F Vendeaud Busquet, JM Bressieux, et al. (2006) Ulcères de jambe présentant des signes locaux d'infection: Intérêt du pansement Biatain ${ }^{\circledR}$ argent. JPC Journal des plaies et cicatrisations p. 41-47.

66. Y Zheng, Y Liang, D Zhang, X Sun, L Liang, et al. (2018) Gelatin-Based Hydrogels Blended with Gellan as an Injectable Wound Dressing. ACS Omega 3(5): 4766-4775.

67. Poursamar SA, Hatami J, Lehner AN, da Silva CL, Ferreira FC, et al (2015) Gelatin porous scaffolds fabricated using a modified gas foaming technique: Characterisation and cytotoxicity assessment. Materials Science and engineering: C 48: 63-70.

68. C Burton, F Blun (1989) Douderm CGF in treatment of chronic stasis ulcers. Aprospective comparison of two hidrocoloid dressing underneath a modified unna boot. American Academy of Dermatology, Summer Session.

69. I Engelberg, J Kohn (1991) Physico-mechanical properties of degradable polymers used in medical applications: a comparative study. Biomaterials 12: $292-304$

70. J Su, L Chen, L Li (2012) Characterization of polycaprolactone and starch blends for potential application within the biomaterials field. African Journal of Biotechnology 11(3): 694-701.

71. C Choong, J Triffitt, Z Cui (2004) Polycaprolactone scaffolds for bone tissue engineering: effects of a calcium phosphate coating layer on osteogenic cells. Food and Bioproducts Processing 82(2): 117-125.

\section{ISSN: 2574-1241}

DOI: $10.26717 /$ BJSTR.2020.24.003997

Mahsa Mollapour Sisakht. Biomed J Sci \& Tech Res

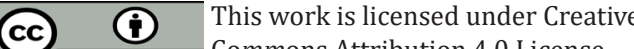

Submission Link: https://biomedres.us/submit-manuscript.php
72. RH Schmedlen, KS Masters, JL West (2002) Photocrosslinkable polyvinyl alcohol hydrogels that can be modified with cell adhesion peptides for use in tissue engineering. Biomaterials 23(22): 4325-4332.

73. SU Maheshwari, SV Kumar, N Nagiah, TS Uma (2013) Electrospinning of polyvinylalcohol-polycaprolactone composite scaffolds for tissue engineering applications. Polymer bulletin 70(11): 2995-3010.

74. Y Huang, T Wang, X Zhao, X Wang, L Zhou, et al. (2015) Poly (lactic acid)/graphene oxide-ZnO nanocomposite films with good mechanical, dynamic mechanical, anti-UV and antibacterial properties. Journal of Chemical Technology \& Biotechnology 90(9): 1677-1684.

75.J Vandeputte, P Van Waeyenberge (2007) Clinical evaluation of L-Mesitran (R)-a honey-based wound ointment: clinical. Professional Nursing Today 11(2): 26-31.

76. Kotz P, Fisher J, McCluskey P, Hartwell SD, Dharma H (2009) Use of a new silver barrier dressing, ALLEVYN? Ag in exuding chronic wounds. International wound journal 6(3): 186-194.

77. Avruscio G, Tocco Tussardi I, Bordignon G, Vindigni V (2017) Implementing clinical process management of vascular wounds in a tertiary facility: Impact evaluation of a performance improvement project. Vascular Health and Risk Management 13: 393-401.

78. S Stringfellow, F Russell, P Cooper, D Gray (2003) Modern wound management: an update of common products. Nursing and Residential Care 5(7): 322-334.

79. C Weller, G Sussman (2006) Wound dressings update. Journal of pharmacy practice and research 36(4): 318-324.

80.https://www.covalon.com/purchase-products/periopertative-carescar-dressing.

81.https://www.medica-tradefair.com/vis/v1/en/exhibitors / medcom2019.2615021.

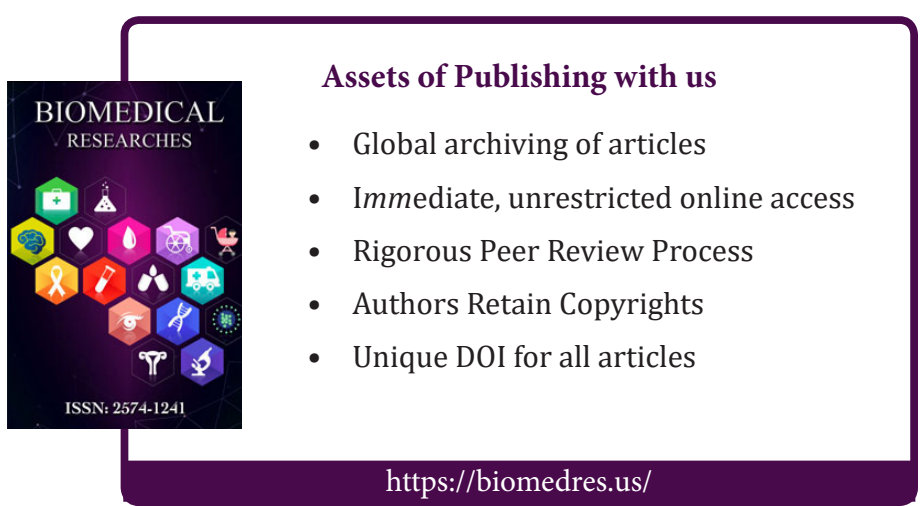

